\title{
Silicon Changes C:N:P Stoichiometry and Favors Pre-Sprouted Seedling Growth, Yield and the Technological Quality of Sugarcane.
}

\section{Tálisson Albiasetti}

São Paulo State University (Unesp)

Jonas Pereira Souza Júnior ( $\nabla$ jonas.psj@hotmail.com )

São Paulo State University (Unesp)

Renato Mello Prado

São Paulo State University (Unesp)

Joaquim José Frazão

São Paulo State University (Unesp)

Marisa de Cássia Piccolo

University of São Paulo (USP)

\section{Research Article}

Keywords: silicon, pre-sprouted seedling, Si fertigation, PSS growth, photosynthetic efficiency

Posted Date: October 13th, 2021

DOl: https://doi.org/10.21203/rs.3.rs-946796/v1

License: (9) This work is licensed under a Creative Commons Attribution 4.0 International License. Read Full License 


\section{Abstract}

The importance of silicon (Si) in sugarcane is well known, but its effects on changing C:N:P stoichiometry enough to increase pre-sprouted seedling (PSS) and sugarcane development in the field remains unknown. To that end, the present study aimed to assess whether Si fertigation favors its absorption enough to change elemental stoichiometry (C:N:P), physiological attributes and PSS growth, as well as the growth, stem yield and juice quality of sugarcane. Two field experiments were conducted in the PSS formation stage and another in the sugarcane plant development phase. Experiment 1 was carried out in a greenhouse with PSSs under two treatments: in the absence and presence of $\mathrm{Si}\left(2 \mathrm{mmol} \mathrm{L}^{-1}\right)$ fertigation. Experiment 2 was performed in the field in red-yellow argisol with the sugarcane plant undergoing the following treatments: absence of $\mathrm{Si}$ (No Si); Si supplied by fertigation during the PSS formation and sugarcane plant development phases $(\mathrm{Si}-\mathrm{C})$; and $\mathrm{Si}$ supplied during the PSS formation and sugarcane plant development phases $(\mathrm{Si}-\mathrm{M}+\mathrm{C})$. The following were assessed in experiment I: growth, leaf green color index (GCl), chlorophyll fluorescence, C, N, P, and Si content, and C:Si, C:N and C:P stoichiometric ratios. In experiment II, the same stoichiometric ratios were assessed, as well as sugarcane growth, stem yield and juice quality. Si reduced the C:Si, C:N and C:P stoichiometric ratios in PSS. The $\mathrm{C}: \mathrm{Si}$ ratio in the leaves and stems declined with the supply of $\mathrm{Si}$, while the $\mathrm{C}: \mathrm{N}$ and $\mathrm{C}: \mathrm{P}$ ratio in the leaves and stem was higher in plants that received $\mathrm{Si}$ in the $\mathrm{Si}-\mathrm{M}+\mathrm{C}$ treatment. Applying Si fertigation in PSS formation to promote changes in C:N:P stoichiometry favored photosynthetic efficiency and growth. The $\mathrm{Si}-\mathrm{M}+\mathrm{C}$ treatment stood out, since it also caused enough $\mathrm{C}: \mathrm{N}: \mathrm{P}$ stoichiometric changes to increase sugarcane growth, yield and juice quality.

\section{Introduction}

Increased production in the sugar-energy industry has heightened demand for new technologies, including the use of pre-sprouted seedlings (PSS). This system uses fewer seedlings, is less costly, improves phytosanitary conditions and the vigor of a recently formed sugarcane crop, in addition to reducing financial costs when compared to the conventional system [1]. However, given that the PSS system is based on microgemma propagation, nutrient and water reserves for the field-transplanted plant are lower during the most critical development period [2].

One strategy to increase PSS vigor is to apply silicon under water stress conditions [3, 4], but studies are incipient.

The supply of Si during PSS formation, performed during transplantation in the field, may have a residual effect, benefitting sugarcane development and yield, but this has yet to be confirmed. Research on the effect of $\mathrm{Si}$ in field studies on sugarcane formation has shown a rise in crop yield [5,6]. However, these studies were conducted using calcium silicate-based Si sources, which require relatively high doses incorporated into the soil in order to raise soil reactivity and $\mathrm{Si}$ availability. New research to reduce the Si dose applied using highly soluble sources via fertigation is important to optimize the supply of this element and provide high absorption in the sugarcane crop. 
Si favors the growth of different species, especially under abiotic water stress, by reducing oxidative stress [7]. However, its effect on increasing sugarcane yield in the field without apparent stress has been scarcely investigated. There are reports that the element favors chlorophyll content [8] and, consequently, photosynthetic efficiency [9]. New approaches have been discussed to illustrate the benefits of Si for sugarcane. $\mathrm{Si}$ is absorbed in the form of silicic acid and can be deposited on specialized cells [10] or cell walls as amorphous silica in the form of $\mathrm{SiO}_{2} \cdot \mathrm{nH}_{2} \mathrm{O}$ [11]. However, more recent studies have shown that another part of $\mathrm{Si}$ (in smaller amounts) is present in the hemicellulose of the cell wall in bonds with its components $(\mathrm{Si}-\mathrm{O}-\mathrm{C})[12]$. The authors report that the cellulose microfibrils of the Si cell walls are much denser than those without the element.

This part of $\mathrm{Si}$ that forms the organosilicon compound on the cell wall could contribute to a better understanding of its importance in favoring crop growth and yield. This occurs because the energy cost of forming an organosilicon compound is relatively low; in addition, the fact that the compound has a structural function decreases the need for the plant to form new structural compounds for the cell wall [8, 13-15]. Thus, the lower energy expenditure may result in metabolic gains, and Si could favor carbon conversion into biomass, confirmed by the change in $\mathrm{C}, \mathrm{N}$ and $\mathrm{P}$, and consequently $\mathrm{C}: \mathrm{N}: \mathrm{P}: \mathrm{Si}$ stoichiometry. It is important to know whether these elemental stoichiometric changes as a function of $\mathrm{Si}$ application are similar in the different sugarcane growth phases, particularly in the early phase of PSS formation and the complete development phase in the field, and if they affect yield.

With respect to the sugarcane crop, both high stem production and quality are needed, and the amount of sugar produced, and potential sugarcane sugar recovery are attributes that determine the economic yield of the crop. Classic studies reported a direct relation between Si supply and sugarcane sugar production [16-18], but this has yet to be confirmed.

Given the low Si content in soils, especially the weathered variety with a high desilicification rate [19], and because sugarcane accumulates the element [20], the viability of the agronomic use of the element in the crop increases. Thus, answers are needed to a number of hypotheses for this new PSS-based sugarcane production: (i) Si fertigation as a soluble source is enough to increase sugarcane absorption of the element; (ii) fertigation with Si favors growth in the PSS formation phase; (iii) transplanting Si-treated PSSs to the field may have a residual effect and raise sugarcane production; (iv) and complementary Si fertigation in this phase in the field, associated with the use of Si-treated PSS, could boost the growth, yield and juice quality of sugarcane. The mechanisms involved in promoting Si benefits in the PSS and sugarcane formation phases are due to the elemental stoichiometric changes in the $\mathrm{C}: \mathrm{N}: \mathrm{P}$, thereby saving energy and benefitting the different sugarcane growth phases.

In order to test these hypotheses, the present study assessed whether Si fertigation favors its absorption enough to change elemental stoichiometry (C:N:P), physiological attributes, and PSS growth, in addition to the growth, yield and juice quality of sugarcane plants.

\section{Results}




\section{Experiment I.}

Silicon and pre-sprouted sugarcane seedling production. Si fertigation was efficient in providing this element for sugarcane PSSs. The PSSs that received Si via fertigation accumulated $0.07 \mathrm{mg}$ of Si per PSS, that is, a $57 \%$ increase when compared to the PSSs grown without Si fertigation $(0.03 \mathrm{mg}$ of Si per PSS) (Fig. 1a).

Si fertigation in PSSs also resulted in physiological improvements, raising pigment production, as estimated by the green color index (GCl) (Fig. 1b). The GCl in PSSs that received Si via fertigation was higher (14) when compared to the absence of this element (11). Additionally, supplying Si to PSSs also decreased energy losses among photosystems, as determined by initial $\left(F_{0}\right)$ (Fig. 1C) and maximum fluorescence $\left(F_{m}\right)$ (Fig. 1d) of 66 and 292, respectively.

Seedling development was favored in plants that received $\mathrm{Si}$, since it raised the height (Fig. 1e), stem diameter (Fig. 1f), leaf area (Fig. 1g) and shoot dry weight (Fig. 1h), compared to untreated plants.

C, N, P, Si concentration and stoichiometry. Si fertigation decreased C leaf area (Fig. 2a), raised Si leaf content (Fig. 2b) and did not influence N (Fig. 2c) and P leaf content (Fig. 2d) in PSSs.

\section{Experiment II.}

Silicon leaf content and sugarcane development and yield. Si fertigation during PSS formation and sugarcane plant development $(\mathrm{Si}-\mathrm{M}+\mathrm{C})$, was the most efficient in raising Si leaf content in sugarcane. Although inferior to the Si-M+C treatment, Si fertigation only during the PSS formation phase (Si-M) or only during the sugarcane plant development phase (Si-C) were also efficient in increasing Si leaf content (Fig. 3a).

Sugarcane plant development was favored by Si fertigation, underscoring the $\mathrm{Si}-\mathrm{M}+\mathrm{C}$ treatment, which increased plant height and stem diameter most (Fig. 3b and 3c), followed by Si-M and Si-C, which were superior to the control treatment without $\mathrm{Si}$ (No Si). With respect to stem yield (Fig. 3d), the best treatments, in ascending order, were No Si, Si-M, Si-C and Si-M+C.

Concentration of C, N, P, Si and stoichiometry. Leaf (Fig. 4a) and stem C content (Fig. 5a) were high in plants not supplied with $\mathrm{Si}$, but declined after this element was applied, reaching the lowest value with the Si-M+C treatment.

The highest increase in leaf (Fig. 3a) and stem Si content (Fig. 5b) was observed in the Si-M+C treatment. Applying Si during the sugarcane development phase ( $\mathrm{Si}-\mathrm{C}$ ) was efficient in raising leaf and stem $\mathrm{Si}$ content, without changing the amount during the seedling formation phase (Si-M).

Leaf (Fig. 4b) and stem N content (Fig. 5c) as well as leaf P content (Fig. 4c) declined with Si application. The lowest leaf and stem $\mathrm{N}$ content occurred in plants submitted to the Si-M+C treatment, and the lowest 
leaf P content in Si-M+C and Si-C treatments. Stem P content was not affected by the treatments (Fig. $5 d)$.

The leaf (Fig. 4d) and stem C:Si ratio (Fig. 5e) decreased with Si application and was highest in the absence of Si (No Si), followed by the Si-M, Si-C and Si-M+C treatments.

The leaf (Fig. 4e) and stem C:N ratio (Fig. 5f) was higher in treatments Si-C and Si-M+C. The leaf (Fig. 4f) and stem C:P ratio (Fig. $5 \mathrm{~g}$ ) was highest in the $\mathrm{Si}-\mathrm{M}+\mathrm{C}$ treatment and in the absence of $\mathrm{Si}$, respectively. Although the leaf N:P ratio was not influenced by the treatments (Fig. $4 \mathrm{~g}$ ), it declined in the stem with the use of $\mathrm{Si}$, reaching its lowest value in the $\mathrm{Si}-\mathrm{M}+\mathrm{C}$ treatment (Fig. $5 \mathrm{~h}$ ).

Technological quality of the sugarcane juice. Supplying $\mathrm{Si}$, irrespective of the mode (Si-M, Si-C or Si-M+C) and time of application, increased the ${ }^{\circ}$ Brix (Fig. 6a) and apparent sucrose percentage in the juice (Fig. 6b), in addition to decreasing the reducing sugar percentage (Fig. 6d). Moreover, applying Si in conjunction during the two sugarcane development phases raised the recoverable sugar percentage in the juice (Fig. 6c).

\section{Discussion}

The excellent Si absorption ability of sugarcane is due to the fact that the crop belongs to the family Poaceae, which contains specialized proteins for the root absorption of Si [21], with a high content in the shoots (>10 $\mathrm{g} \mathrm{kg}^{-1}$ of $\left.\mathrm{Si}\right)$, classifying the plant as a Si accumulator [20].

Thus, different studies with Si application were conducted, especially incorporated into the soil, with different calcium silicate-based sources, demonstrating a rise in the element in the leaves of sugarcane cultivated in the plant-cane or ratoon-cane phase [19-21]. However, information on its application with highly soluble sources in fertigation are incipient, with a single study supplying the element in the presprouted seedling production phase, affecting initial sugarcane growth 30 days after transplanting $[3,25]$.

The present study confirmed that Si fertigation is efficient in increasing the element in PSSs (Fig. 1a). However, when it is associated with PSS formation and during sugarcane growth, it raises leaf and stem Si content (Fig. 3a). Thus, our study demonstrates, for the first time, the importance of Si fertigation in PSS formation, since it influences the contents of this element in sugarcane leaves and stems. The high Si uptake by PSSs and the sugarcane plants is due to the high absorption efficiency of the element and the use of soluble sources applied in solution with no risk of polymerization. As such, Si fertigation is highly feasible, since the amount of the element applied can be decreased, reaching $135 \mathrm{~g} \mathrm{~kg}^{-1}$ with $16.44 \mathrm{~kg} \mathrm{ha}^{-1}$ of $\mathrm{Si}$ in the Si-M+C treatment, a value significantly higher if calcium silicate is incorporated into the soil, as reported by McCray and Ji [22], where Si content was $10 \mathrm{~g} \mathrm{~kg}^{-1}$ with $6 \mathrm{Mg} \mathrm{kg} \mathrm{ha}^{-1}$, without losing efficiency.

The high Si content in the plant resulting from the treatments that change $\mathrm{C}, \mathrm{N}$ and $\mathrm{P}$ content in PSS leaves (Fig. 2e-g) as well as sugarcane leaves (Fig. 5e-g) and stems (Fig. 5e-g) altered the elemental 
stoichiometry of these organs. This could have occurred because after $\mathrm{Si}$ is absorbed by the plant, it may bind to organic compounds $[4,8,13-15]$, especially with the hemicellulose components present in the cell wall [12]. The primary role of hemicellulose is to tie cellulose microfibrils together, thereby strengthening the cell wall and influencing its structure and properties [26].

This effect of Si may generate a "low-cost energy" strategy, since incorporating this element as a structural component can substitute, for example, the energetically more costly lignin biosynthesis [13, 15 ,27]. In the case of sugarcane, the average lignin fraction is nearly $23 \%$ of biomass [28]. In the present study, Si decreased C concentration and leaf C:Si stoichiometric ratio in the PSS production phase (experiment I), corroborating Frazão et al. [8], as well as in the leaves and stems during plant development, which is the first report in this plant, although there are indications in other species such as peanut [29], rice [13] and quinoa [30]. It is believed that the decline in C content in the plant is due to the fact that Si absorption is an "exchange strategy" between Si and a number of organic compounds [13, 31], but this could increase the cost of Si absorption. Another more feasible hypothesis is the fact that when Si forms an organosilicon compound it decreases the synthesis of organic compounds, especially for the cell wall.

We also found that Si decreased the $\mathrm{C}: \mathrm{N}$ and $\mathrm{C}: \mathrm{P}$ ratios in the PSS phase, but raised them during sugarcane plant development (except leaf C:P). This can be explained by the effect of Si on $\mathrm{N}$ and $\mathrm{P}$ absorption efficiency in the young plant (PSS), whose root system is limited in the growth container, unlike the older sugarcane plant, which explores a considerable volume of soil. This Si benefit in the absorption of these nutrients was also observed in other species [15,27,32]. The positive effect of Si on the stoichiometric ratios studied may allow plants to control nutrient balance against possible nutritional disorders in the culture medium, since it is known that Si attenuates $\mathrm{P}$ [33] and $\mathrm{N}$ deficiency [2].

Adequate Si absorption may favor important physiological processes in a plant's life [34], a fact observed in PSS formation, while these effects were not measured in the sugarcane plant. Silicon helped maintain the photosynthesis apparatus [35], preserving photosystem integrity, since it decreased energy losses in the form of fluorescence (Fig. 1c, d) and increased the green color index, an estimate of leaf chlorophyll content (Fig. 2b). This occurs because Si increases the sugarcane antioxidant defense mechanisms [36], decreasing the oxidant action of reactive oxygen species, which degrade the photosynthesis centers [37, 38].

Our results demonstrate the importance of Si fertigation in PSS and sugarcane formation $(\mathrm{Si}-\mathrm{M}+\mathrm{C})$, since the changes in $\mathrm{C}: \mathrm{Si}, \mathrm{C}: \mathrm{N}$ and $\mathrm{C}: \mathrm{P}$ stoichiometric ratios discussed allow the plant to save metabolic energy in order to favor sugarcane growth in the two phases studied and improve sugarcane yield. It was observed, for the first time, that the use of Si-treated PSSs is relevant for sugarcane; however, if its use is precluded, Si fertigation results in greater yield compared to Si fertilization only in the PSS formation phase.

The beneficial effect of Si on the technological quality of sugarcane juice has been reported [39-42], although there may be differences according to the cultivars studied [40]. We found that supplying Si- 
$\mathrm{M}+\mathrm{C}$ and $\mathrm{Si}-\mathrm{C}$ was sufficient to increase ${ }^{\circ} \mathrm{Brix}$ and sucrose and decrease reducing sugars, but the former Si application mode stood out for raising total recoverable sugars (TRS), thereby favoring the technological quality of the sugarcane juice (Fig. 6). This is because Si induces sugar production in the leaves and transports it to the sugarcane stems [16-18]. The enzymatic action of $\mathrm{Si}$ in the stem delays the inverse reactions and the terminal oxidation of sugars, increasing sucrose production and decreasing reducing sugars [17]. Added to this is the fact that Si deposited on the cell wall can regulate the transport of soluble sugars via physiological or physical mechanisms not described by the authors [43].

Given the results presented, all the hypotheses can be accepted, since they sustain the feasibility of $\mathrm{Si}$ fertigation in the two sugarcane growth phases studied. Thus, the present study proposes that Si be supplied by fertigation ( $2 \mathrm{mmol} \mathrm{L}^{-1}$ ) in PSS formation and that it be used for transplanting in the field, initiating the seven Si fertigations $\left(2 \mathrm{mmol} \mathrm{L}^{-1}\right)$ after 30 days with a 30-day interval during sugarcane plant formation. This unprecedented Si fertigation strategy with a soluble source in the form of stabilized potassium silicate will increase the sustainability of this new sugarcane production system with global applications, given the low Si available in tropical and subtropical soils.

\section{Material And Methods}

Description of the study and field site.Two experiments were conducted with sugarcane PSS (CTC 4 variety): experiment I in a greenhouse, to assess the effect of Si on sugarcane PSS formation and experiment II, carried out in the field to observe the effect of Si on the yield and technological quality of sugarcane. Both experiments took place in the municipality of Monte Azul Paulista, São Paulo state, Brazil ( $\left.20^{\circ} 58^{\prime} 16^{\prime \prime} \mathrm{S} 48^{\circ} 29^{\prime} 82^{\prime \prime} \mathrm{W}\right)$. According to Köppen, the climate of the region is classified as humid tropical (Aw), with a wet summer and dry winter. Rainfall $(\mathrm{mm})$ and minimum and maximum temperatures $\left({ }^{\circ} \mathrm{C}\right)$ were recorded during the experimental period (Fig. 7).

The soil in the experimental area was classified as red-yellow argisol ${ }^{44}$. Soil samples were taken from the 0 to $20 \mathrm{~cm}$ layer, dried and the following attributes determined: $\mathrm{H}\left(\mathrm{CaCl}_{2}\right): 5.8 ; \mathrm{P}$ (resin): $7.0 \mathrm{mg} \mathrm{dm}^{-3}$; organic matter: $11 \mathrm{~g} \mathrm{dm}^{-3} ; \mathrm{K}: 2.2 \mathrm{mmol}_{\mathrm{C}} \mathrm{dm}^{-3} ; \mathrm{Ca}: 28 \mathrm{mmol}_{\mathrm{C}} \mathrm{dm}^{-3} ; \mathrm{Mg}^{-3} 9.0 \mathrm{mmol}_{\mathrm{C}} \mathrm{dm}^{-3} ; \mathrm{S}: 3.8 \mathrm{mg} \mathrm{dm}^{-3}$; H+Al: 14.0 mmol $_{\mathrm{C}} \mathrm{dm}^{-3}$; Al: $0.05 \mathrm{cmol}_{\mathrm{C}} \mathrm{dm}^{-3}$; B: $0.18 \mathrm{mg} \mathrm{dm}^{-3}$; Cu: $2.5 \mathrm{mg} \mathrm{dm}^{-3}$; Fe: $30.5 \mathrm{mg} \mathrm{dm}^{-3}$; Mn: 12.1 mg dm${ }^{-3} ; \mathrm{Zn}: 16.5 \mathrm{mg} \mathrm{dm}^{-3}$; clay: $20.1 \%$; silt: $5.6 \%$ and sand: $74.3 \%$. Chemical and granulometric analyses were conducted according to Raij et al. [ 45] and Donagema et al. [ 46 ], respectively. In addition, soil Si content was $8 \mathrm{mg} \mathrm{dm}^{-3}$, in line with the method proposed by Korndörfer et al. [ 47 ].

\section{Experiment I - Silicon in the development of sugarcane PSSs}

Description of the study and field site. Sugarcane PSSs were obtained from plants grown in the field, from which $4 \mathrm{~cm}$-long setts were cut from the mother plant, including the selection of the most vigorous gemmae. Next, the gemmae were thermally treated with hot water $\left(52^{\circ} \mathrm{C}\right)$ for 30 minutes [ 48 ], in addition to treatment with $0.1 \%$ Azoxystrobin in solution to disinfect and eliminate pathogens, primarily ratoon stunting disease caused by the bacteria Leifsonia xylisub sp. [ 49 ]. 
After treatment, the gemmae were stored in a wooden box with a layer of inert substrate containing a 1:1:1 mixture of vermiculite, charcoal and pine bark. Seedlings with the best sprout emergence were selected.

The substrate used received $2 \mathrm{~g} \mathrm{~L}^{-1}$ of potassium chloride, $3 \mathrm{~g} \mathrm{~L}^{-1}$ of ammonium sulphate and $0.66 \mathrm{~g} \mathrm{~L}^{-1}$ of monoammonium phosphate. In addition, growth regulators $\left(0.05 \mathrm{~g} \mathrm{~L}^{-3}\right.$ of 4-indole-3-butyric acid; $0.05 \mathrm{~g}$ $\mathrm{L}^{-3}$ of gibberellic acid; $0.09 \mathrm{~g} \mathrm{~L}^{-3}$ of kinetin) were applied to the gemmae, using a backpack sprayer in order to strengthen initial gemma rooting.

Experimental design. The experimental design with the PSSs was completely randomized, with two treatments: with and without Si fertigation $\left(2 \mathrm{mmol} \mathrm{L}^{-1}\right)$, and 25 repetitions. Each experimental unit consisted of a PSS, transplanted to $0.18 \mathrm{~m}^{3}$ tubes filled with the same substrate mentioned earlier and fertilized during the sprout emergence phase.

Stabilized potassium silicate was used as Si source (SiKE; Si: $115 \mathrm{~g} \mathrm{~L}^{-1} ; \mathrm{K}_{2} \mathrm{O}: 113.85 \mathrm{~g} \mathrm{~L}^{-1}$; sorbitol: 100 $\left.\mathrm{mL} \mathrm{L}^{-1} ; \mathrm{pH}: 12.0\right)$ with $\mathrm{pH}$ adjusted to $7.0 \pm 0.1$ by an $\mathrm{NaOH}(1 \mathrm{M})$ or $\mathrm{HCl}(1 \mathrm{M})$ solution. $\mathrm{K}$ content was balanced between treatments, applying $54.6 \mathrm{mg} \mathrm{L}^{-1}$ of $\mathrm{K}$ in the form of $\mathrm{KCl}$.

Si fertigations were initiated immediately after PSS transplantation to the tubes, where they were kept for 45 days. To that end, irrigation was carried out twice a day with $60 \mathrm{~mL}$ of solution, enough to avoid leaching: one between 6 and 7 am and the other between 5 and $6 \mathrm{pm}$. During sprinkler-based Si fertigations, applied $10 \mathrm{~cm}$ above the plants and reaching the leaves and substrate, temperature, relative humidity and wind speed were $\leq 25^{\circ} \mathrm{C}, \geq 60 \%$ and $\leq 6 \mathrm{~km} \mathrm{~h}^{-1}$, respectively, considered favorable for applying the element [ 34 ].

Physiological and biometric assessments. At 45 days after seedling transplantation, physiological assessments were conducted on the leaf +1 (first fully developed leaf with apparent sheath) to determine the green color index $(\mathrm{GCl})$, as well as initial $\left(\mathrm{F}_{0}\right)$ and maximum $\left(\mathrm{F}_{\mathrm{m}}\right)$ fluorescence.

The GCl was measured using a chlorophyll meter (Opti-Sciences ${ }^{\circledR} \mathrm{CCM}-200$ ), at five points on the middle third of the leaf +1 , to obtain the average value. $F_{0}$ and $F_{m}$ were measured based on chlorophyll fluorescence with the help of a fluorometer (Opti-Sciences ${ }^{\circledR}$ OS30P). Assessments were carried out between 7 and 9 am on the middle third of the leaf +1 , kept in the dark for a 30-minute adaptation period, excited by a 1-second red light pulse, followed by $F_{0}$ and $F_{m}$ measurement.

Also measured were height, from the base of the stem to insertion of the leaf +1 using a tape measure, and stem diameter with a digital pachymeter at ground level. The shoots were collected and separated, and leaf area was measured with an Area Meter ${ }^{\circledR}(\mathrm{L}-3100$, Li-Cor).

Si content and accumulation in the PSS. At the end of biometric assessments, the stem and leaves of the PSS were washed in the following sequence: in running water, neutral detergent solution $(0.1 \%), \mathrm{HCl}$ 
solution ( $0.1 \%)$, and deionized water. Next, the samples were dried in a forced air oven at $65 \pm 5^{\circ} \mathrm{C}$ until constant mass, weighed to obtain shoot dry weight, ground in a Wiley mill and Si content determined in the PSS shoots

Si content was measured based on plant matter digestion in the presence of $\mathrm{H}_{2} \mathrm{O}_{2}$ and $\mathrm{NaOH}$ in an oven at $90 \pm 5^{\circ} \mathrm{C}{ }^{50}$. Colorimetric reading was performed in a spectrophotometer due to the reaction with ammonium molybdate, in the presence of hydrochloric acid and oxalic acid [ 47 ]. Si accumulation was calculated from the product of Si content and shoot dry weight production in sugarcane PSS.

\section{Experiment II - Effect of silicon on sugarcane technological quality and yield}

Preparation of the experimental area, design, experimental plot and treatment application. Experiment II was conducted under field conditions in red-yellow argisol and aimed to assess the effect of Si on sugarcane development.

A randomized block design was used with four treatments and five repetitions. The following treatments were applied: absence of Si (No Si); Si supplied during PSS formation (Si-M); Si supplied during the sugarcane development phase $(\mathrm{Si}-\mathrm{C})$; and $\mathrm{Si}$ supplied during the PSS and sugarcane development phases $(\mathrm{Si}-\mathrm{M}+\mathrm{C})$. The Si source used was the same as in experiment I (SiKE) at a concentration of 2 mmol L-1 with pH adjusted to 7.0 using a $\mathrm{NaOH}(1 \mathrm{M})$ or $\mathrm{HCl}(1 \mathrm{M})$ solution; and the amount of $\mathrm{K}$ obtained from the Si source was balanced among the treatments.

The experimental plot consisted of five 3-meter-long rows spaced 1.5 meters apart with $0.5 \mathrm{~m}$ between plants. The study area was composed of the three middle rows, using two central meters of length, totaling $6 \mathrm{~m}^{2}$.

The experimental area was plowed, harrowed and furrows opened at a depth of $25 \mathrm{~cm} \pm 5 \mathrm{~cm}$ for PSS transplantation. Fertilizer consisting of $60 \mathrm{~kg} \mathrm{ha}^{-1}$ of $\mathrm{N}, 210 \mathrm{~kg} \mathrm{ha}^{-1}$ of $\mathrm{P}_{2} \mathrm{O}_{5}$; and $120 \mathrm{~kg} \mathrm{ha}^{-1}$ of $\mathrm{K}_{2} \mathrm{O}$ with 04-14-08 formulation, was applied.

Si was applied via fertigation in treatments $\mathrm{Si}-\mathrm{C}$ and $\mathrm{Si}-\mathrm{M}+\mathrm{C}$ one month after PSS transplantation. During the experimental period, Si was applied seven times, 30 days apart, the first three applications with $60 \mathrm{~L}$ of solution per plot and the others with $100 \mathrm{~L}$ per plot. An $\mathrm{FMC}^{\circledR}$ sprayer was used, with $2000 \mathrm{~L}$ capacity, regulated for an application rate of $800 \mathrm{~L} \mathrm{ha}^{-1}$ of mixture, with a spray gun working pressure of 2 bars.

The meteorological conditions at the moment of application were measured in terms of temperature, relative humidity and wind speed $\left(<26^{\circ} \mathrm{C},>60 \%\right.$ and $<8 \mathrm{~km} \mathrm{~h}^{-1}$, respectively), conditions favorable for foliar application [34 ].

The plants grown in the absence of $\mathrm{Si}$ and those receiving Si only during PSS formation received only water during the treatments. The amount of Si supplied at the end of the experimental period was 0.00 ; 
$0.15 ; 1.083$ and $1.23 \mathrm{~g}$ of Si per seedling for the No Si, Si-M, Si-C and $\mathrm{Si}-\mathrm{M}+\mathrm{C}$ treatments, corresponding to $0.00,2.00,14.44$, and $16.44 \mathrm{~kg} \mathrm{ha}^{-1}$, respectively.

Disease management. Disease management in the field was performed by controlling weeds after planting and pre-emergence of the sugarcane crop with $237.6 \mathrm{~g} \mathrm{ha}^{-1}$ of hexazinone and $842.4 \mathrm{~g} \mathrm{ha}^{-1}$ of diuron. Also applied was $400 \mathrm{~g} \mathrm{ha}^{-1}$ of fipronil $\left(800 \mathrm{~g} \mathrm{~kg}^{-1}\right)$ for insect control.

Leaf sampling and Si analysis in sugarcane. Ten leaves +1 per plot were sampled six months after the last Si fertigation. The leaf samples were decontaminated with water, a neutral detergent solution (1\%), $\mathrm{HCl}$ solution (1\%) and deionized water, then oven dried at $65 \pm 5^{\circ} \mathrm{C}$ until constant weight and ground in a Wiley mill.

Sugarcane yield and technological quality. The experiment was terminated at sugarcane maturity (12 months after planting), the study area harvested, yield estimated and sugarcane technological quality measured.

In order to assess the technological quality of sugarcane, ten plants from each plot were processed, and only the stems separated. The samples were ground and shredded to obtain the juice, which was homogenized. Next, the technological quality of the juice was determined using the CONSECANA method [ 51 ]. To that end, sugar content was quantified ( $\left.{ }^{\circ} \mathrm{BRIX}\right)$ with a digital refractometer, and the percentage apparent mass of sucrose in the juice (Pol) was determined, applying the optical saccharimetry method. Sugar content determined by sacchimetry is considered an optically active substance, corresponding to transparent substances with a lack of symmetry in their crystalline molecular structure and the ability to rotate the polarized light plane. The juice was clarified to allow passage of the polarized light beam through the polarimetric tube using the OCTAPOL clarifying reagent $(\mathrm{OC}-6 \mathrm{~g} / 200 \mathrm{~mL})$.

In addition, total reducing sugar (RS) and total recoverable sugar (TRS) percentages were calculated, with the former determined by the formula:

$$
R S=3.6410-0.0343 \times Q
$$

Where:

$\mathrm{Q}=$ apparent juice purity:

$$
Q=\frac{\text { Pol }}{{ }^{\circ} \text { Brix }}
$$

TRS was calculated by the formula:

$$
T R S=10 \times P C \times 1.05263 \times 0.915+10 \times R S \times 0.915
$$


Where:

$\mathrm{PC}=$ Pol per tonne of cane;

1.05263 = Stoichiometric coefficient for the conversion of Pol into reducing sugars;

0.915 = Recovery coefficient for industrial loss of $8.5 \% ; 10 \mathrm{x}$;

$\mathrm{RS}=$ Reducing sugars per tonne of cane

Determination of Si, C, N and P and stoichiometry in PSS and sugarcane. Chemical analysis was conducted in the PSS leaves and the leaves and stems of field-grown sugarcane. The Si content in the plant matter was determined based on alkaline digestion with $\mathrm{H}_{2} \mathrm{O}_{2}$ and $\mathrm{NaOH} 50$, and the colorimetric reaction with ammonium molybdate, obtained by colorimetric reading in a spectrophotometer [ 47 ]. Carbon $(\mathrm{C})$ and nitrogen $(\mathrm{N})$ content were determined by dry combustion $\left(1000^{\circ} \mathrm{C}\right)$ using an elemental analyzer (LECO truspec CHNS), calibrated with the LECO standard 502-278 (C=45.00\%). P content was determined using the molybdenum-antimony colorimetric method in a spectrophotometer, as described by Batablia et al. [ 52 ].

The Si, C, N and P contents were used to obtain the C:Si, C:N and C:P stoichiometric ratios in these PSS and sugarcane tissues.

Statistical analysis. The data of both experiments were submitted to analysis of variance (F-test) and, when significant, were compared by Tukey's test at 5\% probability. Statistical analyses were carried out in Sisvar ${ }^{\circledR}$ software[ 54 ] and the graphs constructed using the SigmaPlot $12.5^{\circledR}$ program.

\section{Conclusions}

Si fertigation in PSS formation promoted changes C:N:P stoichiometry, thereby favoring photosynthetic efficiency and growth. The $\mathrm{Si}-\mathrm{M}+\mathrm{C}$ treatment stood out, since it also caused enough stoichiometric changes in C:N:P to increase sugarcane growth, yield and juice quality.

\section{Declarations}

\section{Acknowledgements}

The support of the São Paulo State University (UNESP) is gratefully acknowledged.

\section{Author contributions}

T. A. and J.P.S.J. conducted the experiments and wrote the manuscript, being responsible for the analysis in general. R.M.P., J.P.S.J, M.C.P and J.J.F. T.A. and J.P.S.J contributed to the manuscript writing. J.P.S.J 
and R.M.P. contributed to the analysis of data and creation of graphs. T.A. collected the data.

All authors contributed to the revision of the manuscript.

\section{Competing interests}

The authors declare no competing interests.

\section{Additional information}

Correspondence and requests for materials should be addressed to J.P.S.J.

The experimental research was carried out in compliance with relevant institutional, national and international guidelines and legislation

\section{References}

1. Landel, M. G. A. et al. Sistema de multiplicação de cana-de-açúcar com uso de mudas pré-brotadas (MPB) , oriundas de gemas individualizadas [Multiplication system of sugarcane using pre-sprouted seedlings (MPB), from individualized buds]. (Instituto Agronômico de Campinas, 2012).

2. da Silva, P. P. et al. Path analysis for selection of drought tolerant sugarcane genotypes through physiological components. Ind. Crops Prod. 37, 11-19 (2012).

3. Teixeira, G. C. M. et al. Silicon in pre-sprouted sugarcane seedlings mitigates the effects of water deficit after transplanting. J. Soil Sci. Plant Nutr. 1-11 (2020) doi:10.1007/s42729-019-00170-4.

4. Oliveira Filho, A. S. B. et al. Silicon attenuates the effects of water deficit in sugarcane by modifying physiological aspects and C:N:P stoichiometry and its use efficiency. Agric. Water Manag. 255, 107006 (2021).

5. Savant, N. K., Korndörfer, G. H., Datnoff, L. E. \& Snyder, G. H. Silicon nutrition and sugarcane production: A review. J. Plant Nutr. 22, 1853-1903 (1999).

6. Camargo, M. S. \& Keeping, M. G. Silicon in Sugarcane: Availability in Soil, Fertilization, and Uptake. Silicon 1-11 (2021) doi:10.1007/s12633-020-00935-y.

7. Cooke, J. \& Leishman, M. R. Consistent alleviation of abiotic stress with silicon addition: a metaanalysis. Funct. Ecol. 30, 1340-1357 (2016).

8. Frazão, J. J., Prado, R. de M., de Souza Júnior, J. P. \& Rossatto, D. R. Silicon changes C:N:P stoichiometry of sugarcane and its consequences for photosynthesis, biomass partitioning and plant growth. Sci. Rep. 10, 12492 (2020).

9. Santos, L. C. N., Teixeira, G. C. M., Prado, R. de M., Rocha, A. M. S. \& Pinto, R. C. dos S. Response of pre-sprouted sugarcane seedlings to foliar spraying of potassium silicate, sodium and potassium silicate, nanosilica and monosilicic acid. Sugar Tech 1-9 (2020) doi:10.1007/s12355-020-00833-y.

10. Kumar, S. \& Elbaum, R. Interplay between silica deposition and viability during the life span of sorghum silica cells. New Phytol. 217, 1137-1145 (2018). 
11. Kim, S. G., Kim, K. W., Park, E. W. \& Choi, D. Silicon-induced cell wall fortification of rice leaves: A possible cellular mechanism of enhanced host resistance to blast.

http://dx.doi.org/10.1094/PHYT0.2002.92.10.1095 92, 1095-1103 (2007).

12. He, C., Ma, J. \& Wang, L. A hemicellulose-bound form of silicon with potential to improve the mechanical properties and regeneration of the cell wall of rice. New Phytol. 206, 1051-1062 (2015).

13. Klotzbücher, T. et al. Variable silicon accumulation in plants affects terrestrial carbon cycling by controlling lignin synthesis. Glob. Chang. Biol. 24, e183-e189 (2018).

14. Mantovani, C., Prado, R. M. \& Pivetta, K. F. L. Silicon foliar application on nutrition and growth of Phalaenopsis and Dendrobium orchids. Sci. Hortic. (Amsterdam). 241, 83-92 (2018).

15. Neu, S., Schaller, J. \& Dudel, E. G. Silicon availability modifies nutrient use efficiency and content, C:N:P stoichiometry, and productivity of winter wheat (Triticum aestivum L.). Sci. Rep. 7, 1-8 (2017).

16. Ayres, A. S. Calcium silicate slag as a growth stimulant for surgarcane on low-soils. Soil Sci. 103, 216-227 (1966).

17. Alexander, A. G. Enzyme-sugar relationships in immature sugarcane treated with ascorbic acid, cysteine, hydroxylamine, cyanide, silicon, and iron. J. Agric. Univ. Puerto Rico 51, 46-54 (1969).

18. Samuels, G. \& Alexander, A. G. Influence of variable manganese and silicon on the nutrition, sugar production, and enzyme activity of immature sugarcane. J. Agric. Univ. Puerto Rico 53, 14-27 (1969).

19. Vander Linden, C. \& Delvaux, B. The weathering stage of tropical soils affects the soil-plant cycle of silicon, but depending on land use. Geoderma vol. 351 209-220 (2019).

20. Deshmukh, R., Sonah, H. \& Belanger, R. New evidence defining the evolutionary path of aquaporins regulating silicon uptake in land plants. J. Exp. Bot. (2020) doi:10.1093/jxb/eraa342.

21. Mitani, N., Yamaji, N. \& Ma, J. F. Identification of maize silicon influx transporters. Plant Cell Physiol. 50, 5-12 (2009).

22. McCray, J. M. \& Ji, S. Sugarcane yield response to calcium silicate on Florida mineral soils. J. Plant Nutr. 41, 2413-2424 (2018).

23. Rhodes, R., Miles, N. \& Hughes, J. C. Interactions between potassium, calcium and magnesium in sugarcane grown on two contrasting soils in South Africa. F. Crop. Res. 223, 1-11 (2018).

24. Keeping, M. G. Uptake of silicon by sugarcane from applied sources may not reflect plant-available soil silicon and total silicon content of sources. Front. Plant Sci. 8, 760 (2017).

25. Teixeira, G. C. M., Prado, R. de M., Rocha, A. M. S. \& Piccolo, M. de C. Root- and foliar-applied silicon modifies C: N: P ratio and increases the nutritional efficiency of pre-sprouted sugarcane seedlings under water deficit. PLoS One 15, e0240847 (2020).

26. Scheller, H. V. \& Ulvskov, P. Hemicelluloses. Annu. Rev. Plant Biol. 61, 263-289 (2010).

27. Raven, J. A. The transport and funcion of silicon in plants. Biol. Rev. 58, 179-207 (1983).

28. Arni, S. Al. Extraction and isolation methods for lignin separation from sugarcane bagasse: A review. Ind. Crops Prod. 115, 330-339 (2018). 
29. Fernandes, S., Pereira Da Silva, G., Prado, R. D. M. \& Rossatto, D. R. Association of root and leaf silicon application decreases the $\mathrm{C} / \mathrm{Si}$ ratio, increasing carbon gain and dry mass production in peanut plants. Commun. Soil Sci. Plant Anal. 1-9 (2021) doi:10.1080/00103624.2021.1928168.

30. Lata-Tenesaca, L. F., de Mello Prado, R., de Cássia Piccolo, M., da Silva, D. L. \& da Silva, J. L. F. Silicon modifies C:N:P stoichiometry, and increases nutrient use efficiency and productivity of quinoa. Sci. Rep. 11, 9893 (2021).

31. Schoelynck, J. et al. Silica uptake in aquatic and wetland macrophytes: A strategic choice between silica, lignin and cellulose? New Phytol. 186, 385-391 (2010).

32. Greger, M., Landberg, T. \& Vaculík, M. Silicon influences soil availability and accumulation of mineral nutrients in various plant species. Plants 7, 41 (2018).

33. Silva, J. L. F. da \& Prado, R. de M. Elucidating the action mechanisms of silicon in the mitigation of phosphorus deficiency and enhancement of its response in sorghum plants. J. Plant Nutr. 1-11 (2021) doi:10.1080/01904167.2021.1918155.

34. Prado, R. de M. Mineral nutrition of tropical plants. (Springer Nature Switzerland AG, 2021). doi:10.1007/978-3-030-71262-4.

35. Elsheery, N. I. et al. Foliar application of nanoparticles mitigates the chilling effect on photosynthesis and photoprotection in sugarcane. Plant Physiol. Biochem. 149, 50-60 (2020).

36. Verma, K. K., Singh, P., Singh, R. K. \& Li, Y. The protective role of silicon in sugarcane under water stress: photosynthesis and antioxidant enzymes. Biomed. J. Sci. Tech. Res. 15, 1-7 (2019).

37. Gong, H. \& Chen, K. The regulatory role of silicon on water relations, photosynthetic gas exchange, and carboxylation activities of wheat leaves in field drought conditions. Acta Physiol. Plant. 34, 1589-1594 (2012).

38. Cao, B. L., Ma, Q., Zhao, Q., Wang, L. \& Xu, K. Effects of silicon on absorbed light allocation, antioxidant enzymes and ultrastructure of chloroplasts in tomato leaves under simulated drought stress. Sci. Hortic. (Amsterdam). 194, 53-62 (2015).

39. Camargo, M. S., Bezerra, B. K. L., Vitti, A. C., Silva, M. A. \& Oliveira, A. L. Silicon fertilization reduces the deleterious effects of water deficit in sugarcane. J. Soil Sci. Plant Nutr. 17, 99-111 (2017).

40. Nikpay, A., Nejadian, E. S., Goldasteh, S. \& Farazmand, H. Efficacy of silicon formulations on sugarcane stalk borers, quality characteristics and parasitism rate on five commercial varieties. Proc. Natl. Acad. Sci. India Sect. B Biol. Sci. 87, 289-297 (2017).

41. Ashraf, M. et al. Potassium and silicon improve yield and juice quality in sugarcane (Saccharum officinarum L.) under salt stress. J. Agron. Crop Sci. 195, 284-291 (2009).

42. Shen, X. F., Zhao, Z. H. \& Chen, Y. Effects of intercropping with peanut and silicon application on sugarcane growth, yield and quality. Sugar Tech 21, 437-443 (2019).

43. Zhu, Y. et al. The regulatory role of silicon on carbohydrate metabolism in Cucumis sativus L. under salt stress. Plant Soil 406, 231-249 (2016). 
44. Santos, H. G. et al. Sistema brasileiro de classificação de solos [Brazilian system of soil classification.]. (Embrapa Solos, 2018).

45. Raij, B. Van, Andrade, J. C., Cantarella, H. \& Quaggio, J. A. Análise química para availação da fertilidade de solos tropicais [Chemical analysis to assess the fertility of tropical soils]. (Instituto Agronômico de Campinas, 2001).

46. Donagema, G. K., Campos, D. B. V. B., Calderano, S. B., Teixeira, W. G. \& Viana, J. H. Manual de métodos de análise de solo [Manual of soil analysis methods]. (2011).

47. Kondörfer, G. H., Pereira, H. S. \& Nola, A. Análise de silício: solo, planta e fertilizante [Silicon analyse: soil, plant and fertilizers]. (2004).

48. Sanguino, A., Moraes, V. A. \& Casagrande, M. Curso de formação e condução de viveiros de mudas de cana-de-açúcar [Course of management of sugar cane seedling production]. (2006).

49. Davis, M. J., Gillaspie, A. G., Harris, R. W. \& Lawnson, R. H. Ratoon stunting disease of sugarcane: isolation of the causal bacterium. Science (80- ). 210, 1365-1367 (1980).

50. Kraska, J. E. \& Breitenbeck, G. A. Simple, robust method for quantifying silicon in plant tissue. Commun. Soil Sci. Plant Anal. 41, 2075-2085 (2010).

51. Oliveira, F. M. de et al. Avaliação tecnológica de variedades de cana-de-açúcar [Technology assessment of sugarcane varieties influenced by different fertilization and water stress] [ influenciadas por diferentes adubações e supressões de irrigação. Rev. Ceres 59, 832-840 (2012).

52. Bataglia, O. c., Teixeira, J. P. F., Furlani, P. R., Furlani, A. M. C. \& Gallo, J. R. Métodos de análise química de plantas [Methods of chemical analysis of plants]. (1983).

53. Bataglia, O. c., Teixeira, J. P. F., Furlani, P. R., Furlani, A. M. C. \& Gallo, J. R. Métodos de análise química de plantas. (1983).

54. Ferreira, D. F. Sisvar: a guide for its bootstrap procedures in multiple comparisons. Cienc. $e$ Agrotecnologia38, 109-112 (2014).

\section{Figures}


a)

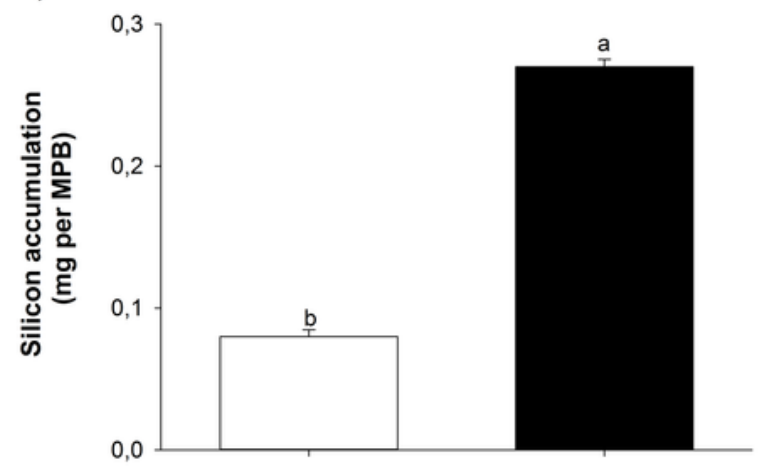

c)

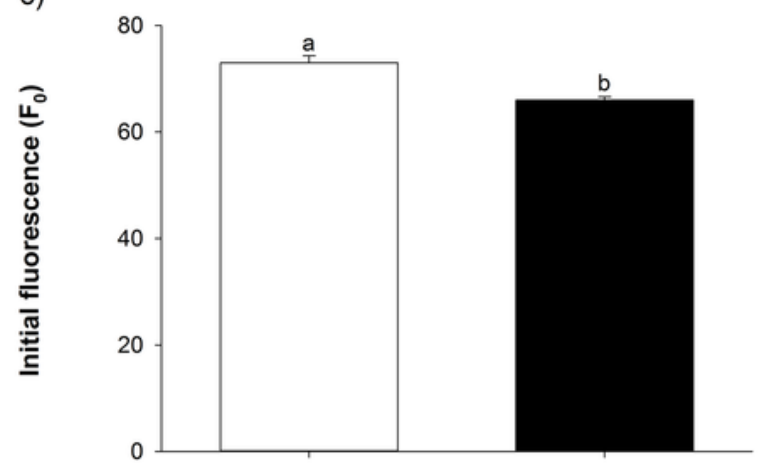

e)

g)

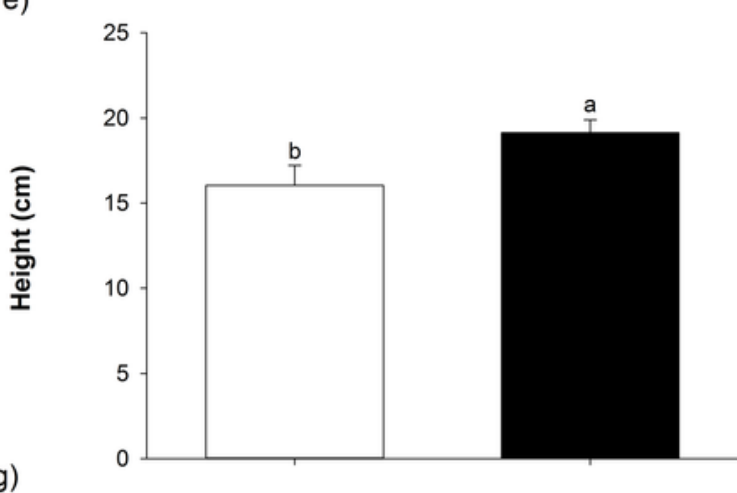

b)

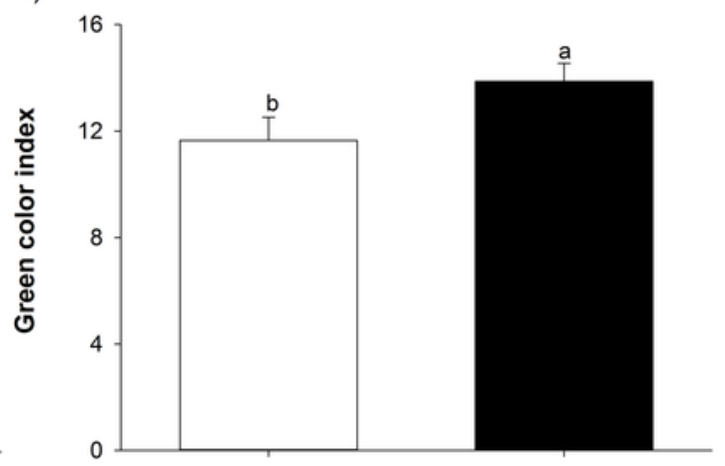

d)

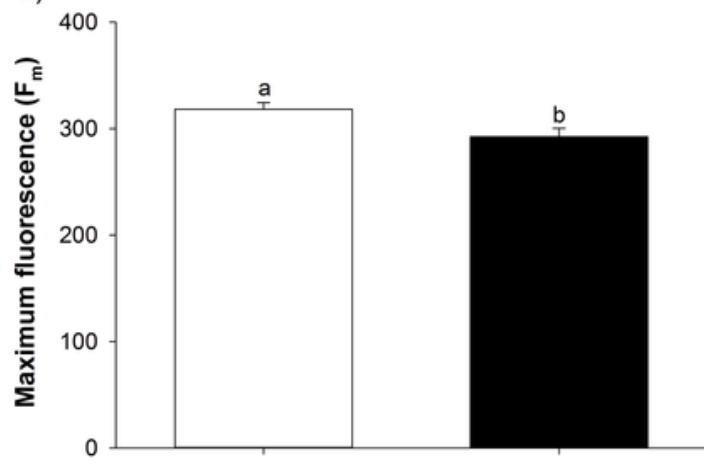

f)

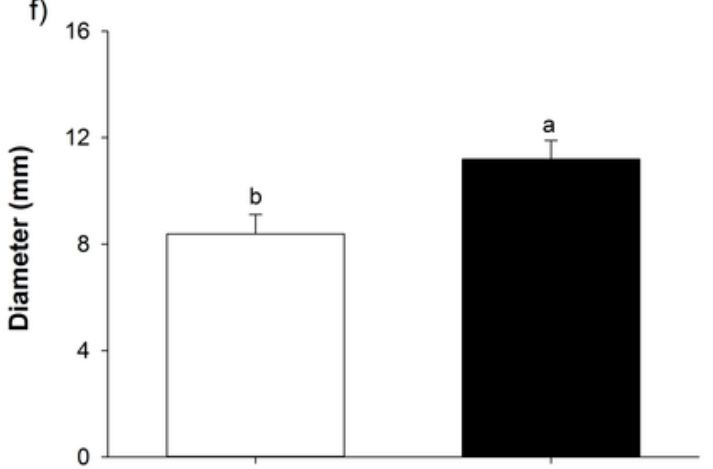

h)

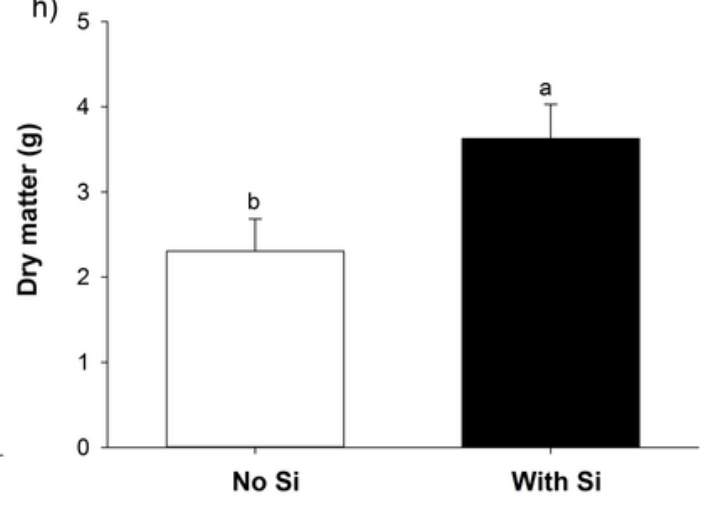

\section{Figure 1}

Si accumulation (a), green color index (b), initial fluorescence (c), maximum fluorescence (d), height (e), diameter $(\mathrm{f})$, leaf area $(\mathrm{g})$ and shoot dry weight $(\mathrm{h})$ of pre-sprouted sugarcane seedlings grown in the absence or presence (2 mmol L-1) of Si, applied via fertigation. Experiment I data. 
a)

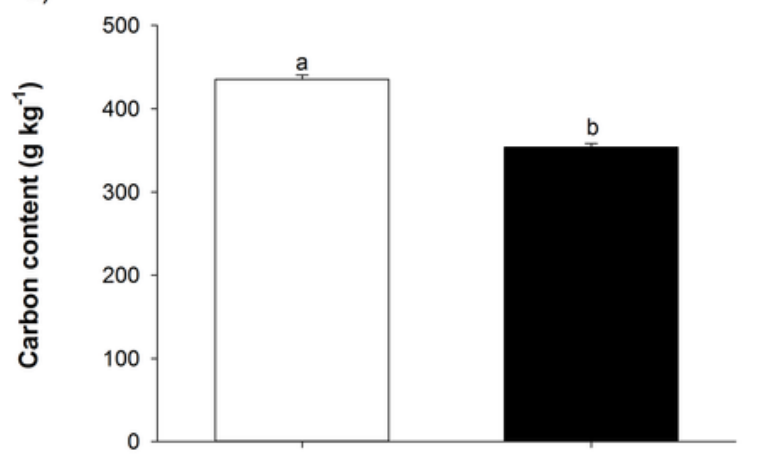

c)

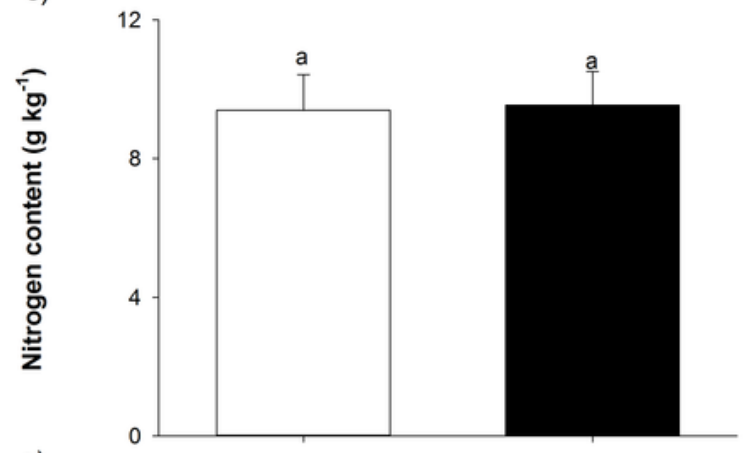

e)
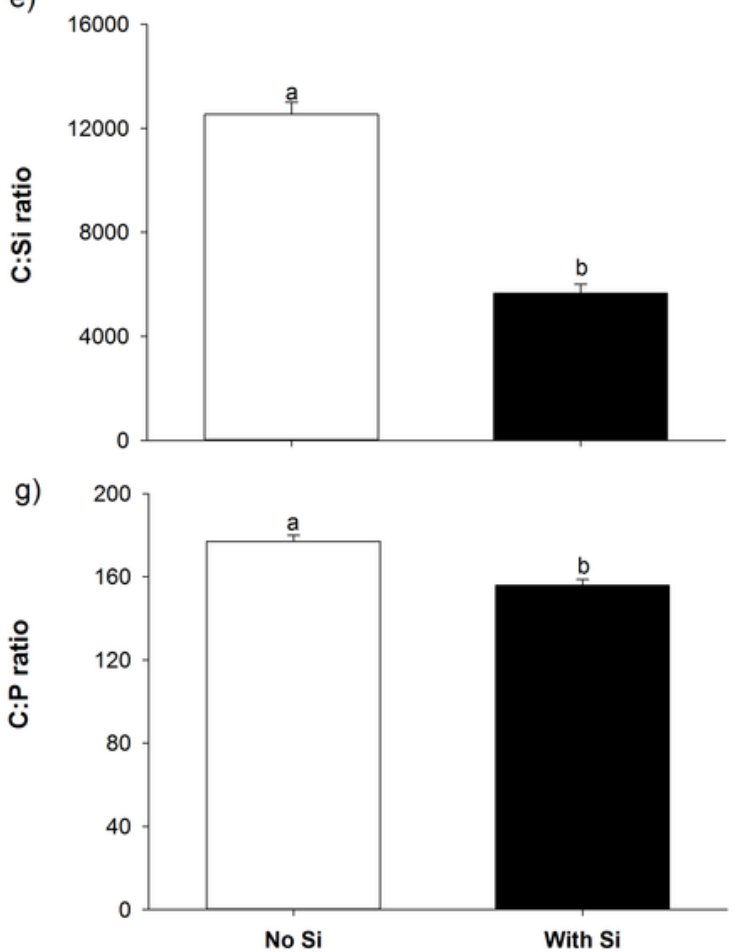

b)

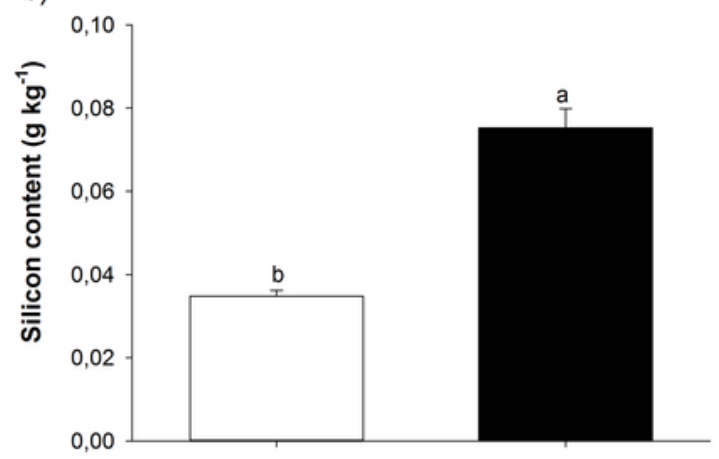

d)
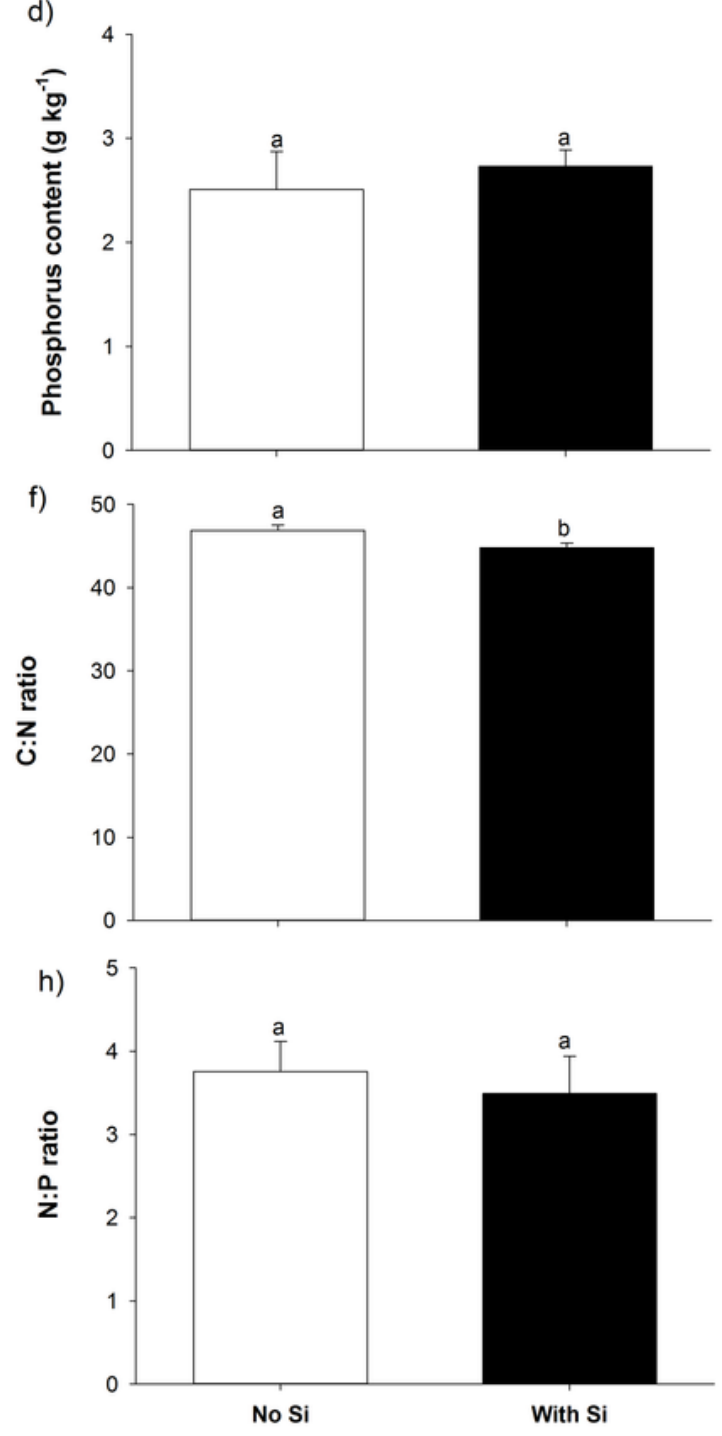

Figure 2

Carbon (C) (a), silicon (Si) (b), nitrogen $(N)(c)$, and phosphorous content $(P)(d)$, and C:Si (e), C:N (f), C:P (g) and N:P (h) ratios in pre-sprouted sugarcane seedling leaves grown in the absence or presence (2 $\mathrm{mmol} \mathrm{L-1)} \mathrm{of} \mathrm{Si,} \mathrm{applied} \mathrm{via} \mathrm{fertigation.} \mathrm{Experiment} \mathrm{I} \mathrm{data.}$ 
a)

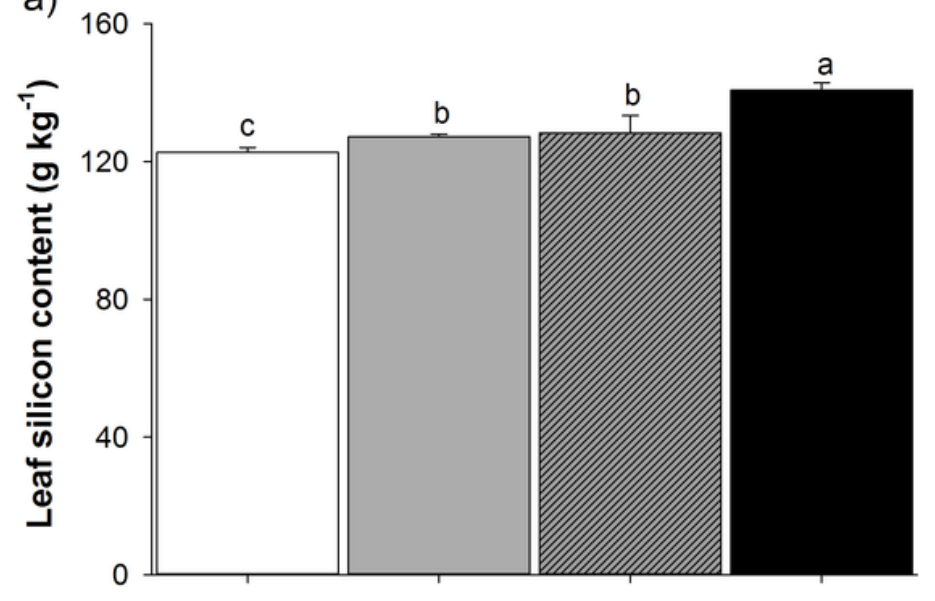

c)

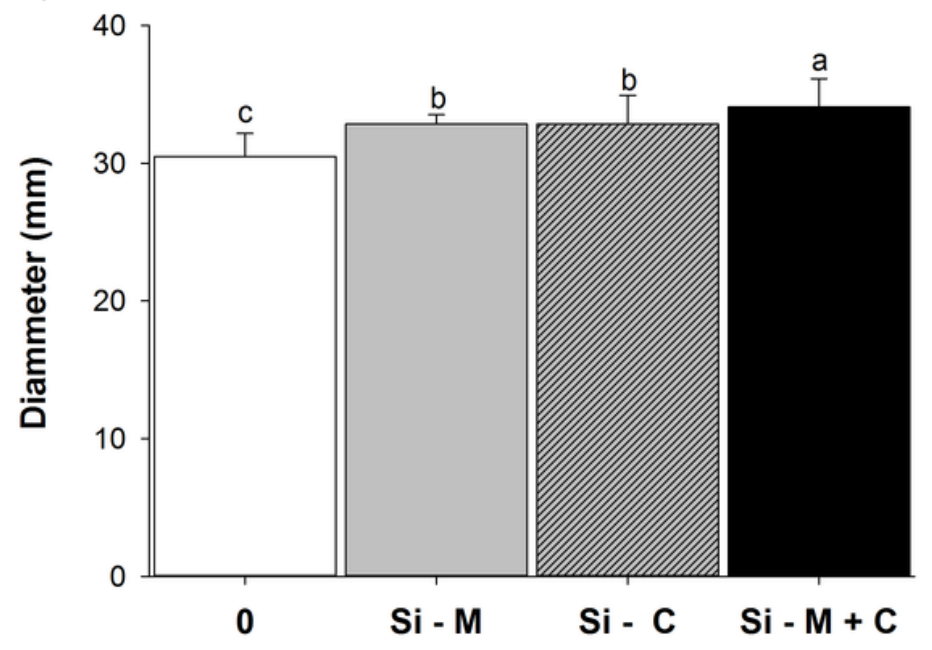

b)

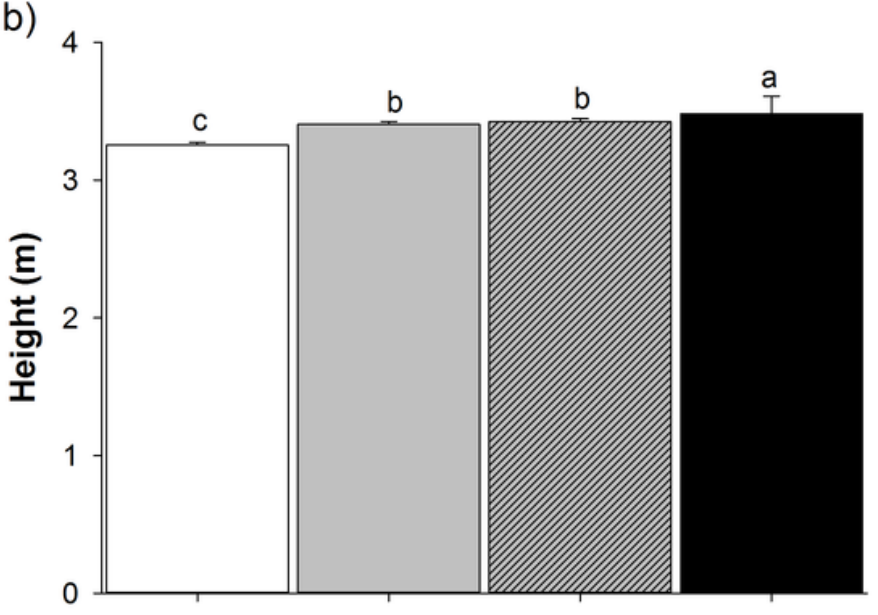

d)

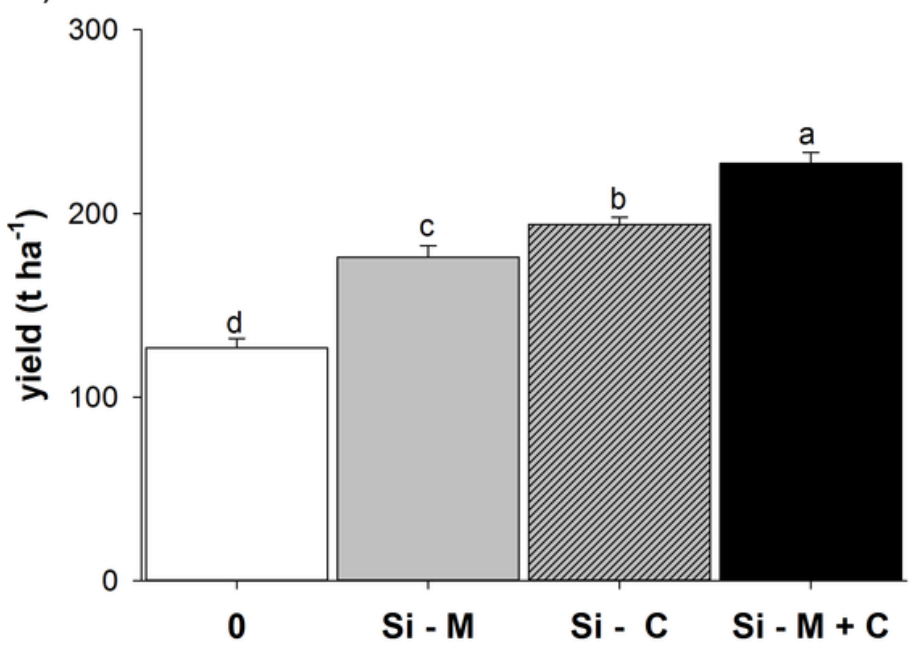

Figure 3

Leaf Si content (a), height (b), diameter (c) and yield (d) of sugarcane grown in the absence or presence of silicon (Si) supplied during different development phases: without Si (No Si), Si supplied only during the seedling formation phase $(\mathrm{Si}-\mathrm{M})$; Si supplied only during the sugarcane plant development phase $(\mathrm{Si}-\mathrm{C})$; and $\mathrm{Si}$ supplied during the seedling formation and sugarcane plant development phase $(\mathrm{Si}-\mathrm{M}+$ C). Experiment II data. 
a)

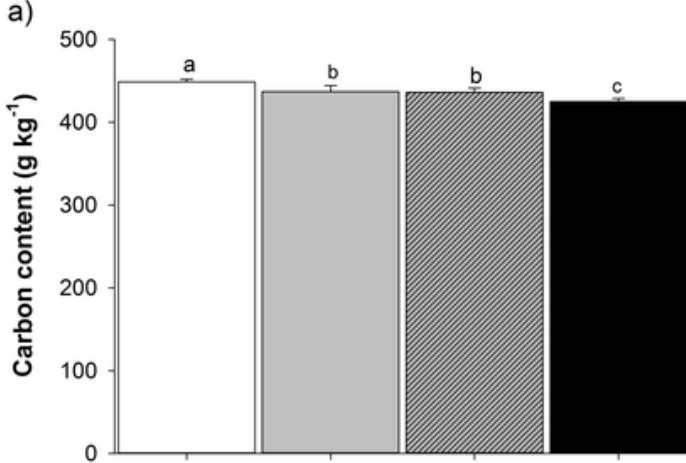

c)

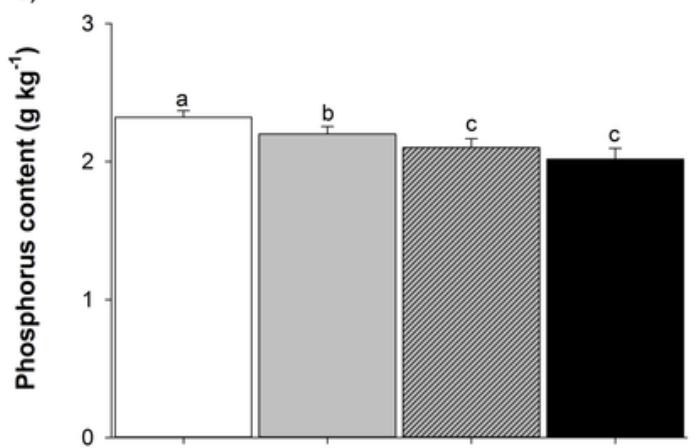

e)

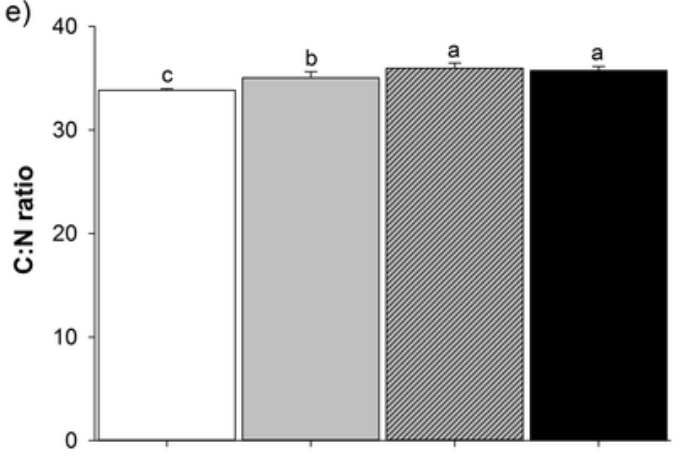

g)

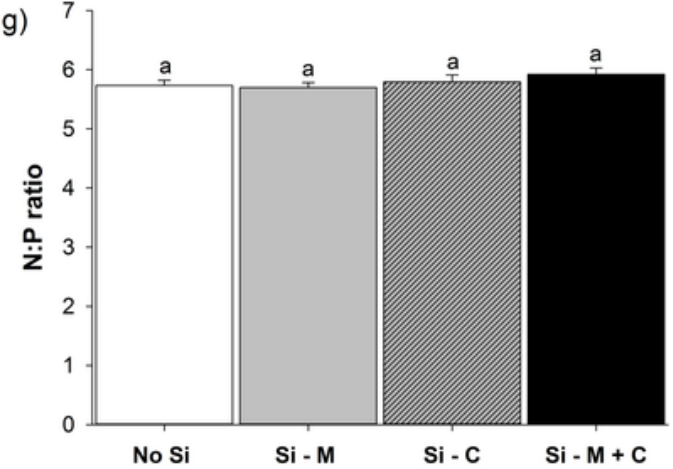

b)

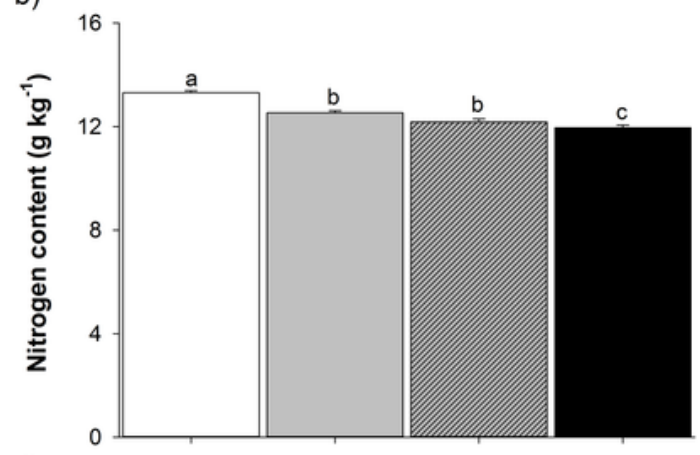

d)
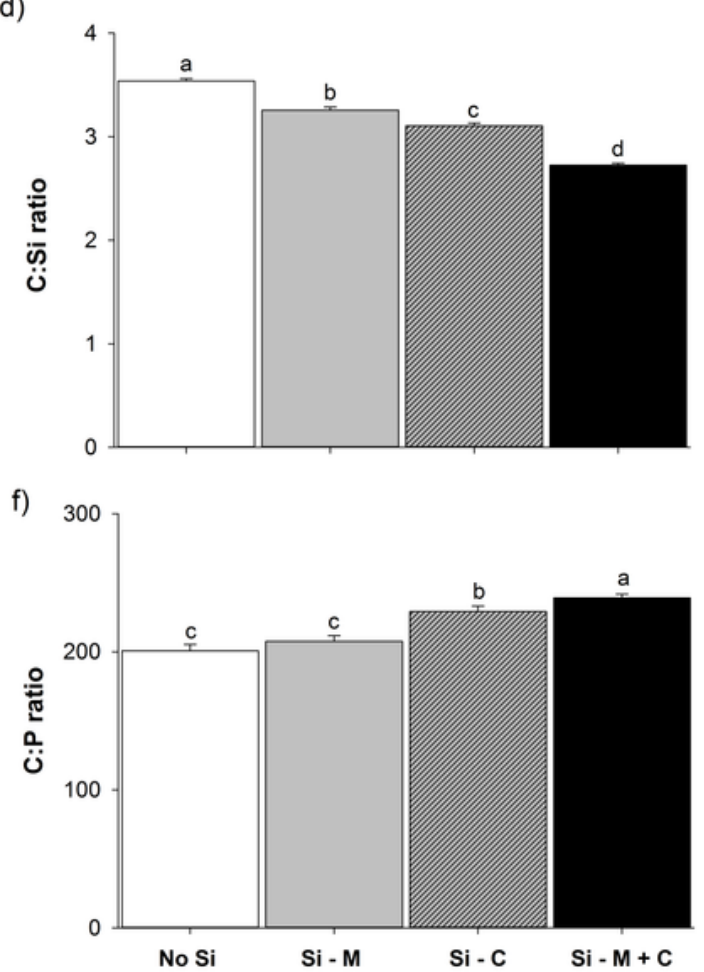

\section{Figure 4}

Carbon $(C)(a)$, nitrogen $(N)(b)$, and phosphorous content $(P)(c)$ and C:Si(d), C:N (e) C:P (f) and N:P ratios (g) in the leaves of sugarcane grown in the absence or presence (2 mmol L-1) of Si, applied via fertigation during different development phases: without $\mathrm{Si}$ (No Si), Si supplied only during the seedling formation phase (Si - M); Si supplied only during the sugarcane plant development phase ( $\mathrm{Si}-\mathrm{C})$; and $\mathrm{Si}$ supplied during the seedling formation and sugarcane plant development phase $(\mathrm{Si}-\mathrm{M}+\mathrm{C})$. Experiment II data. 

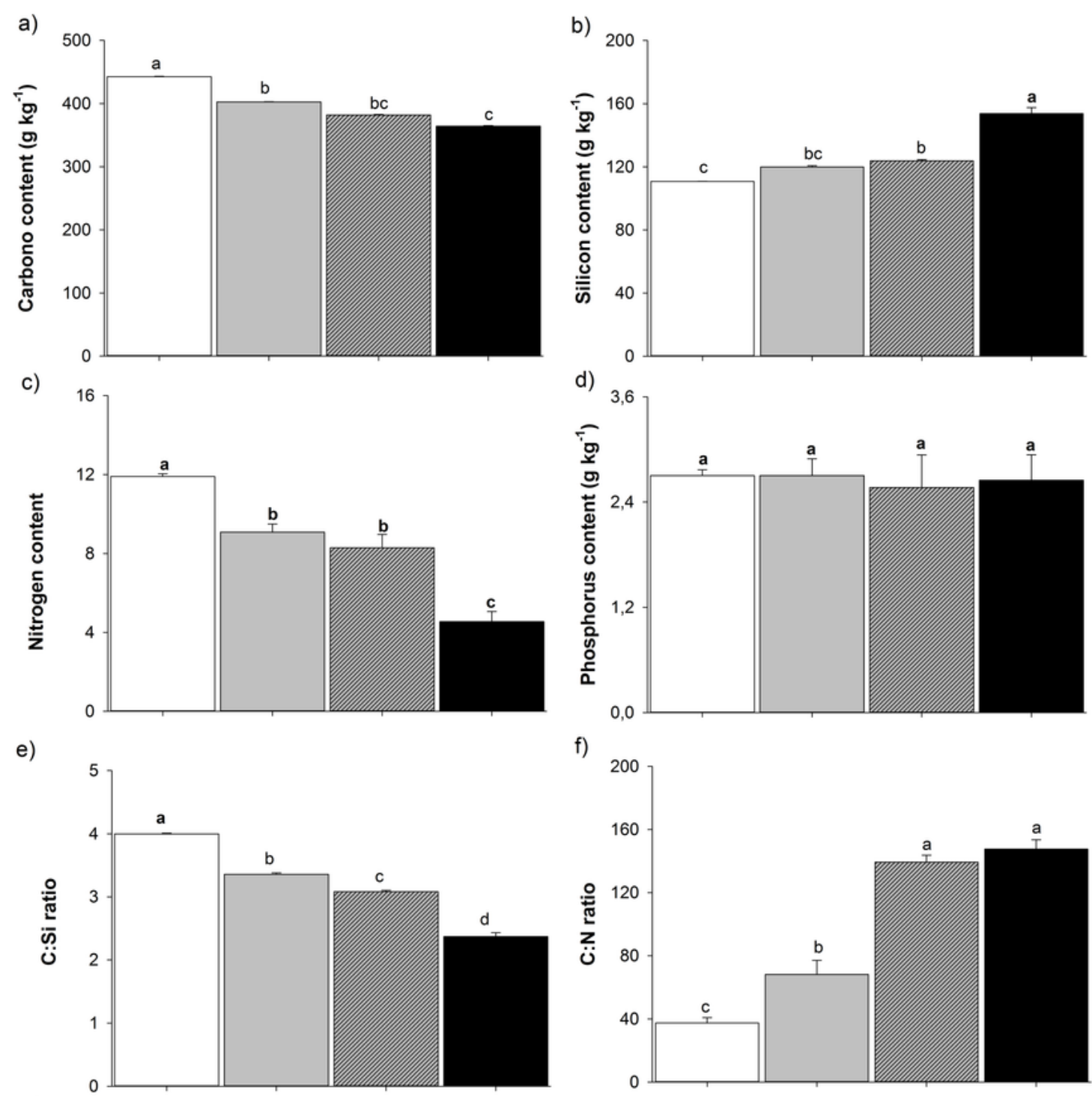

g)
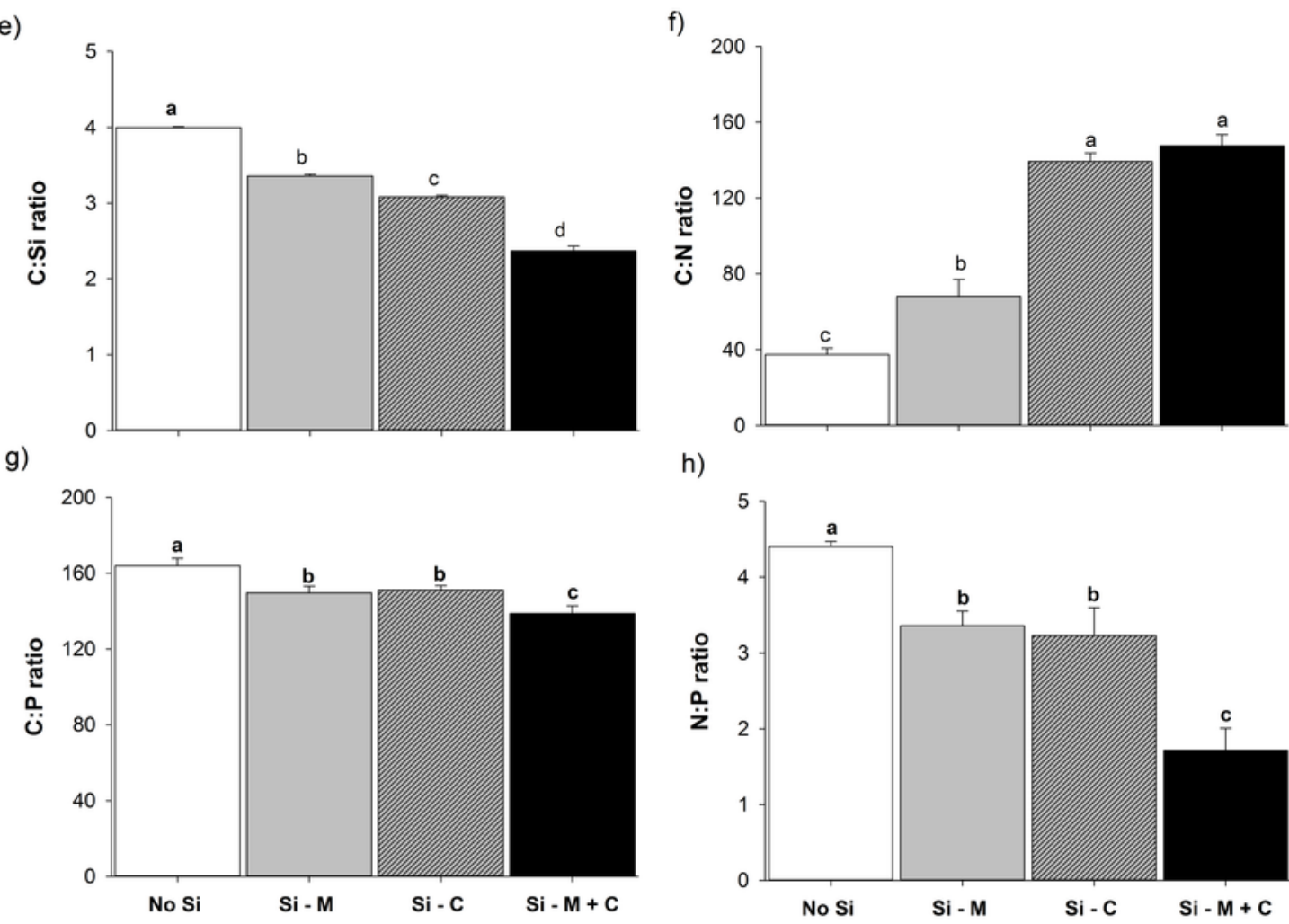

h)

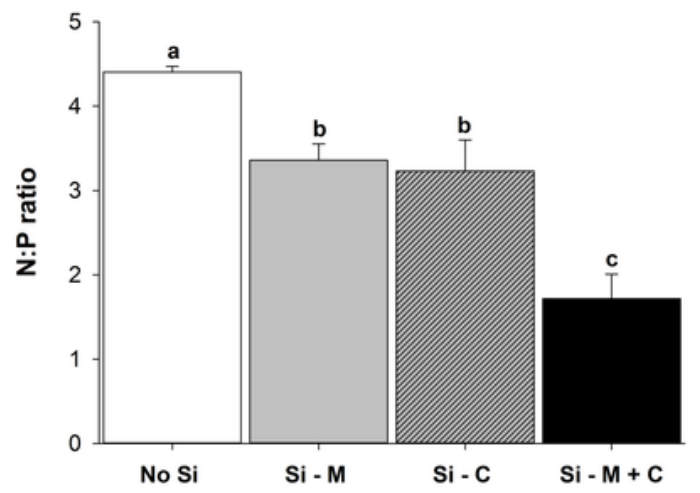

\section{Figure 5}

Carbon (C) (a), nitrogen (N) (b), and phosphorous content (P) (c) and C:Si(d), C:N (e) C:P (f) and N:P ratios (g) in the stems of sugarcane grown in the absence or presence (2 mmol L-1) of $\mathrm{Si}$, applied via fertigation during different development phases: without $\mathrm{Si}$ (No $\mathrm{Si}$ ), Si supplied only during the seedling formation phase $(\mathrm{Si}-\mathrm{M})$; Si supplied only during the sugarcane plant development phase $(\mathrm{Si}-\mathrm{C})$; and $\mathrm{Si}$ supplied during the seedling formation and sugarcane plant development phase $(\mathrm{Si}-\mathrm{M}+\mathrm{C})$. Experiment II data. 
a)

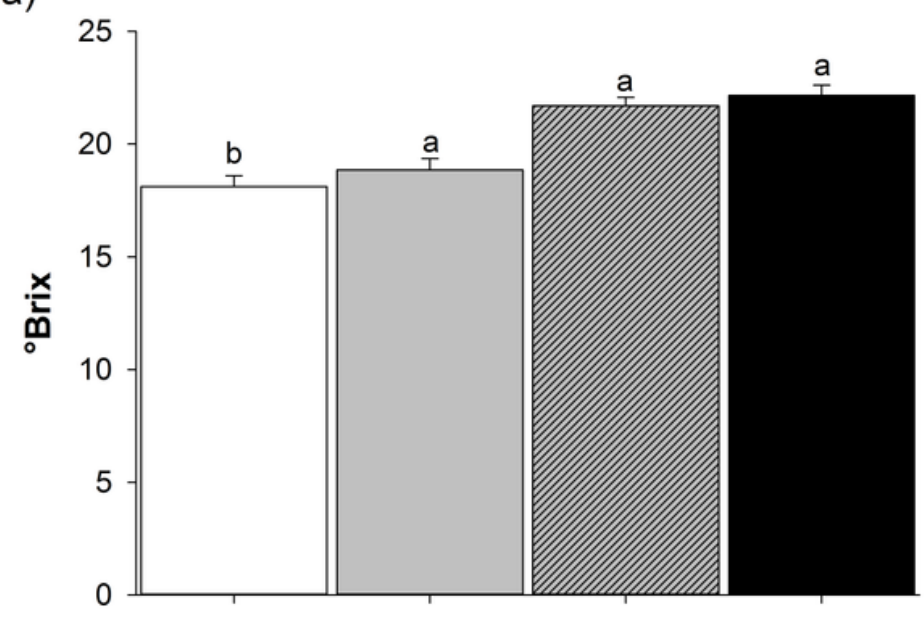

c)

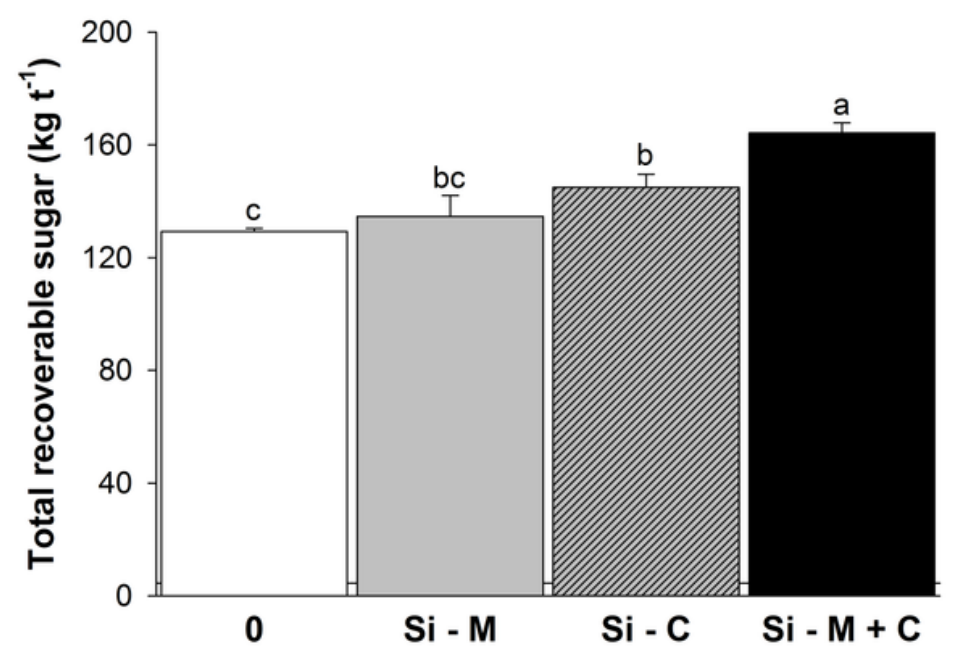

b)

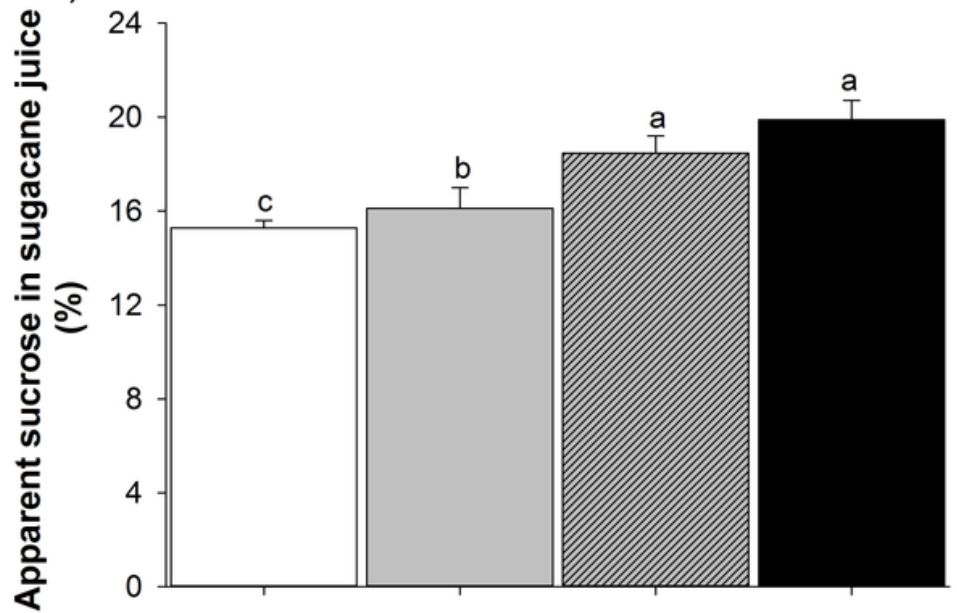

d)

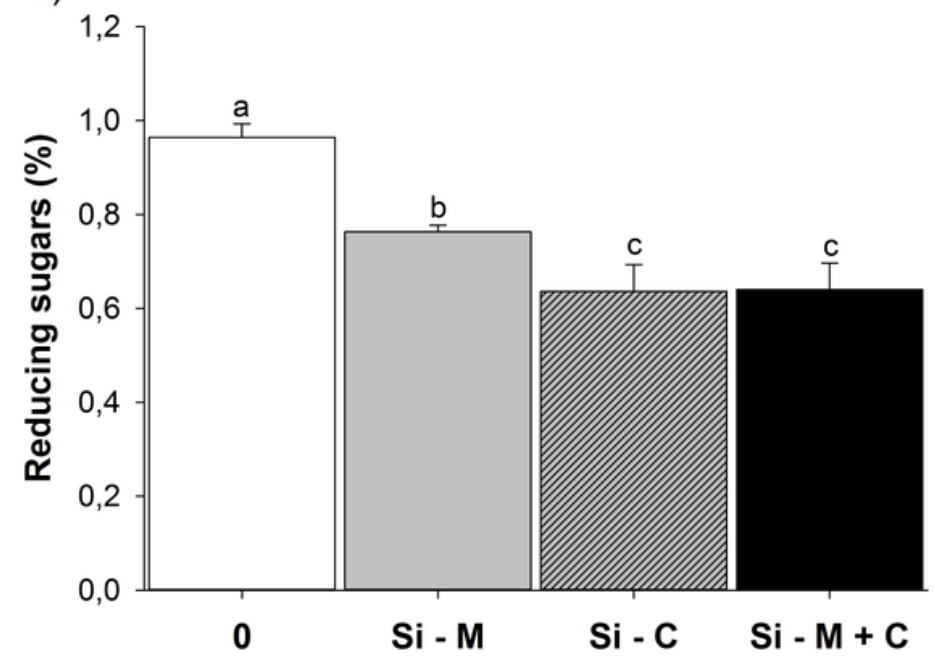

\section{Figure 6}

${ }^{\circ} B$ rix (a), apparent sucrose (b), total recoverable sugar (c) and reducing sugars (d) in the juice of sugarcane grown in the absence and presence of silicon (Si) supplied during different development phases. 


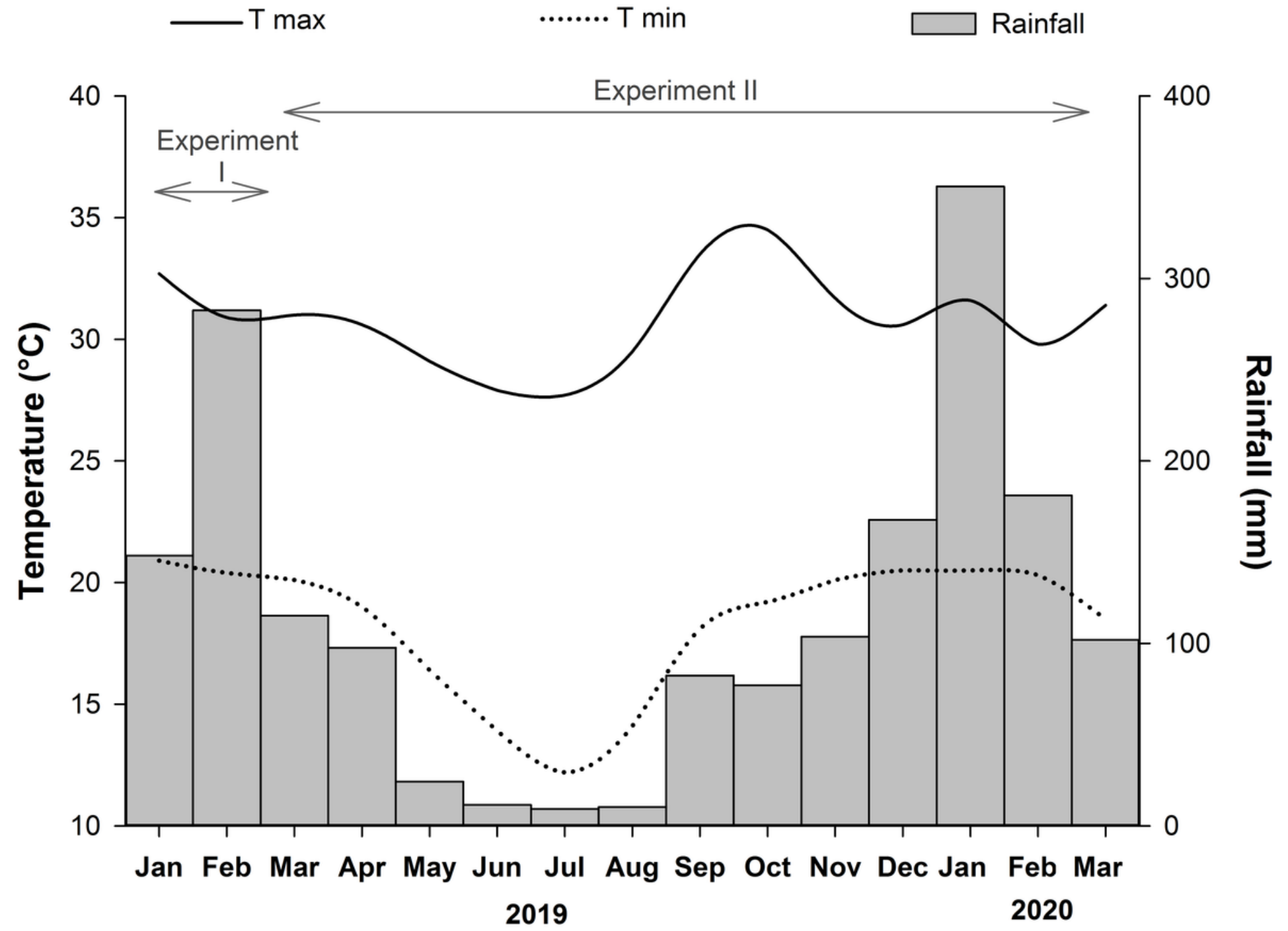

Figure 7

Maximum temperature ( $\mathrm{T}$ max), minimum temperature ( $\mathrm{T}$ min) and rainfall in the experimental area during experiments I and II. 